Esta publicación cientifica en formato digital es continuidad de la revista impresa ISSN-Versión Impresa 0798-1406 / ISSN-Versión on line 2542-3185Depósito legal pp
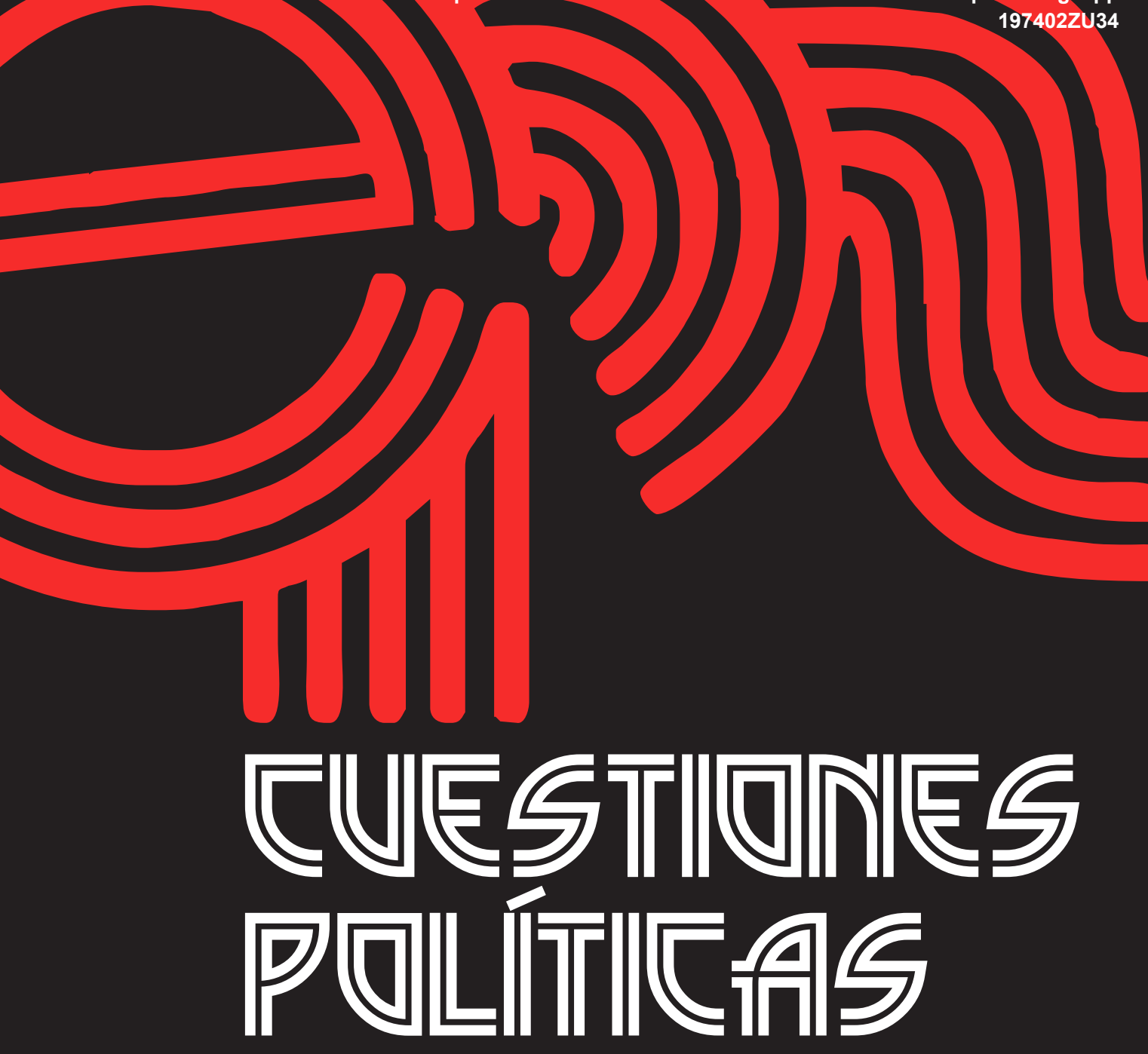

Instituto de Estudios Políticos y Derecho Público "Dr. Humberto J. La Roche" de la Facultad de Ciencias Jurídicas y Políticas de la Universidad del Zulia Maracaibo, Venezuela
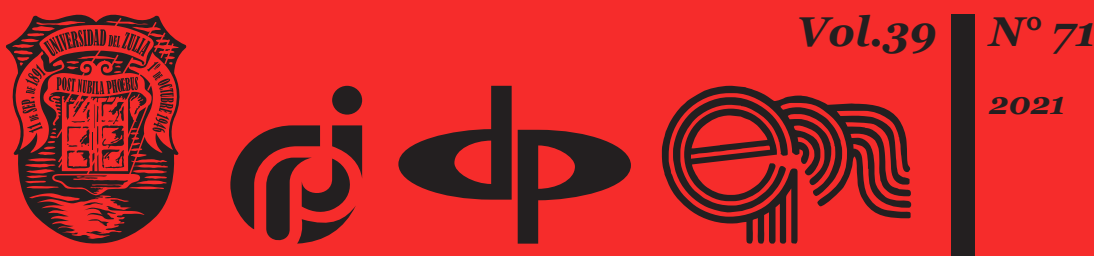


\title{
Influence of cooperative ideologies on the origin of credit societies in Russia
}

\author{
DOI: https://doi.org/10.46398/cuestpol.3971.34
}

Vladislav Vladimirovich Nevlev *

Larisa Vladimirovna Solovyova **

Vladislava Igorevna Solovyova ***

Inna Mikhailovna Nevleva ****

Anastasia Vladislavovna Nevleva $* * * * *$

Vladimir Kuzmich Nevlev ${ }^{* * * * * *}$

\begin{abstract}
The aim of the research was to examine the influence of cooperative ideologies on the origin of credit societies in Russia. The emergence of a legal framework for consumer and, later, credit cooperation in Russia came in two ways. The first formal credit union was established in 1831 by Russian military officers banished to Siberia after the December 1825 revolt. Other cooperatives were organized in a Western model by enthusiasts from the wealthy strata. Later, the history of cooperation in consumer credit before the revolution in Russia can be divided into three stages: first, 1831-1860 (before the peasant reform); second, 1861-1904 (after the peasant reform); and third, 1905-1917 (adoption of government regulations on cooperation). To solve the objective set, the authors used the documentary method close to the historical method. It is concluded that analysis of the preconditions of the first cooperative organizations in Russia shows that there were some known forms of primitive cooperation or pre-cooperation over the
\end{abstract} centuries.

Keywords: classics of cooperation; economic conditions; credit cooperation; legal regulation; history of the ideas of credit societies.

\footnotetext{
* Belgorod University of Cooperation, Economics and Law, Belgorod, Russia. ORCID ID: https://orcid. org/0000-0002-2889-8380

** Belgorod University of Cooperation, Economics and Law, Belgorod, Russia. ORCID ID: https://orcid. org/0000-0002-0091-3374

*** Belgorod University of Cooperation, Economics and Law, Belgorod, Russia. ORCID ID: https://orcid. org/0000-0003-0497-9431

***** Belgorod University of Cooperation, Economics and Law, Belgorod, Russia. ORCID ID: https://orcid. org/0000-0003-2229-9405

****** Belgorod University of Cooperation, Economics and Law, Belgorod, Russia. ORCID ID: https://orcid. org/oooo-0002-2442-9819

****** Belgorod University of Cooperation, Economics and Law, Belgorod, Russia. ORCID ID: https:// orcid.org/00oo-0002-7178-5090
} 
Vladislav Vladimirovich Nevlev, Larisa Vladimirovna Solovyova, Vladislava Igorevna Solovyova, Inna Mikhailovna Nevleva, Anastasia Vladislavovna Nevleva y Vladimir Kuzmich Nevlev

580

Influence of cooperative ideologies on the origin of credit societies in Russia

\section{Influencia de las ideologías cooperativas en el origen de las sociedades de crédito en Rusia}

\section{Resumen}

El objetivo de la investigación fue examinar la influencia de las ideologías cooperativas en el origen de las sociedades de crédito en Rusia. La aparición de un marco legal para la cooperación de consumo y, más tarde, de crédito en Rusia se produjo de dos maneras. La primera cooperativa de crédito formal fue establecida en 1831 por oficiales militares rusos desterrados a Siberia después de la revuelta de diciembre de 1825. Otras cooperativas fueron organizadas en un modelo occidental por entusiastas de los estratos ricos. Más tarde, la historia de la cooperación en crédito al consumo antes de la revolución en Rusia se puede dividir en tres etapas: primero, 18311860 (antes de la reforma campesina); segundo, 1861-1904 (después de la reforma campesina); y tercero, 1905-1917 (aprobación de reglamentos gubernamentales sobre cooperación). Para resolver el objetivo planteado los autores utilizaron el método documental próximo al método histórico. Se concluye que un análisis de las condiciones previas de las primeras organizaciones cooperativas en Rusia muestra que hubo algunas formas conocidas de cooperación primitiva o pre-cooperación a lo largo de los siglos.

Palabras clave: clásicos de la cooperación; condiciones económicas; cooperación crediticia; regulación legal; historia de las ideas de las sociedades de crédito.

\section{Introduction}

A study of the origin and development of cooperation in Russia should involve an analysis of legal regulation. Therefore, the history of consumer cooperation from the second half of the 19th century to the early 2oth century should be taken into account. This would imply a critical review of the impact of Western cooperative practices on the establishment of cooperatives in Russia and an analysis of the legal status of credit cooperatives in legal practices of the 19th century. Terminological approaches to the definitions "credit cooperation" and "cooperation" should be also included with regard to the analyzed period. 


\section{Literature review}

The word "cooperation" comes from Latin and literally means the act of working together. The Brockhaus and Ephron Encyclopedic Dictionary (1895: 156) provides an interpretation of cooperation as: "Any joint effort of several people toward a common shared objective".

Ever since the time of origin of the cooperative movement within the ideological stream of utopian socialists, such as Claude Henri SaintSimon, Charles Fourier and Robert Owen, the idea of cooperation had been understood as a form of economic management opening the potential to transform the socioeconomic formation. Only cooperation, in their view, was capable of reinstating labor as a natural tendency and joy, of combining science and production and smoothing out social disproportions. Assimilation of cooperation with the practical realisation of the principle of mutual assistance and social interaction in economic operation can be found in the works of Herbert Spencer (1898), Auguste Comte (1912), P. A. Kropotkin (1922) and others.

The Russian cooperation scholar V. S. Sadovsky in the 1870 s defined cooperation as the consolidation of productive forces leading to the emergence of new forms of economic management enabling the development of self-governance skills, free exchange of opinions and finding trade-offs (Sadovsky, 1868). A major role in understanding the principles of cooperation was played by the Russian scholar M. I. Tugan-Baranovsky (2010: 94) who observed that a cooperative is an economic enterprise comprising several voluntarily combined people which has as its aim not obtaining the greatest profit on capital expended, but rather increasing the labour income of its members or reducing the outlay of members on their consumer necessities.

An analysis of various definitions of "cooperation" suggests that since the time of origin of the concept, two main approaches had developed, specifically institutional and functional approaches. Institutionally, cooperation is defined as the consolidation of efforts in cooperatives for running joint economic operation and social activities. Under the functional approach, cooperation is primarily joint engagement in some sort of activity for the attainment of a common outcome.

The Brockhaus and Ephron Encyclopedic Dictionary of the late 19th century identifies a specific type of cooperation, namely, credit cooperation existing in two primary forms, mutual loan associations and loan-andsavings societies. The latter refer to alliances of low-resourced individuals needing small loans, established to build up, through gradual small contributions, a more or less significant mutual capital to extend loans to its members and to facilitate borrowings from third parties based on mutual joint liability as may be necessary for running their business or enterprise 
Vladislav Vladimirovich Nevlev, Larisa Vladimirovna Solovyova, Vladislava Igorevna Solovyova, Inna Mikhailovna Nevleva, Anastasia Vladislavovna Nevleva y Vladimir Kuzmich Nevlev

on more favorable terms than would be accessible to them individually. (Brockhaus and Ephron Encyclopedic Dictionary, 1895: 156).

Thus, credit cooperation was understood as a type of cooperation uniting small rural and urban producers, workers and servicemen to establish a mutual cash fund to meet the requirements in small credit. Ideas concerning the nature of credit cooperation at a later stage will be discussed further.

The development of the "cooperative ideology" is credited to the utopian philosophers Charles Fourier and Robert Owen who pioneered the idea of class antagonism in the society, which influenced their understanding of the nature of cooperation. The French scholar Ch. Fourier (1772-1832) believed that the state would become redundant under communal socialism and would only administer minor functions. Fourier believed society was based on a commune he called a phalange (phalanx). He believed that the cooperative ideology was about free labour exercised to attain the personal happiness of community members, understood as the principle of an equitable society. Fourier presented his views in his works, "Théorie des quatre mouvements et des destinées générales" (1808; "The Social Destiny of Man; or Theory of the Four Movements", 1857); "The Theory of Universal Unity" (1822; originally "Traité de l'association agricole domestique", "Treatise on Domestic Agricultural Association") and "Le Nouveau Monde industriel" (1829-30; "The New Industrial World").

The "English" viewpoint on the cooperative ideology is represented by R. Owen (1771-1858). While Fourier was a utopian dreamer who never put his ideas to practice, Owen had had successful experience in managing production. In his first work, "A New View of Society, Or Essays on the Principle of the Formation of the Human Character" (1813-1814), he presented his guiding principles he would stick with in his practice. For him, cooperative communities would be created to change human nature and instill a better moral character. Reviewing Owen's years of educational effort, F. Engels noted, "All social movements and all real advances made in England in the interest of the working class were associated with Robert Owen's name" (Marx and Engels, 1961: 118). The cooperative ideology of Fourier and Owen, as well as their followers later, was rather social than economic.

A Fourier follower, Christian socialist Philippe Buchez (1796-1865), proposed the idea of "production associations" for collective labour and further marketing of the manufactured goods. Part of the proceeds should be distributed to the community fund along the lines of contributions to the church (Bulgakov, 1913). One of Owen's first followers was notably William King (1786-1865). A physician by education, W. King was among the agents of the cooperative movement in practice. He supervised the launch of the monthly journal "The Co-operator" running an active promotion 
of cooperative efforts. The fundamental principle of cooperation for King was free labour for the common good arranged through the establishment of cooperative unions. The cooperative theory credits him with the establishment of the "co-operative socialism" movement.

In France, socialist and economist Pierre-Joseph Proudhon (18091865) proposed the "progressive association" project for a peaceful social reorganisation; he believed social freedom for workers could be attained through production, credit and consumer associations. The first Secretary of the British Co-operative Union E. Vansittart Neale and the prominent cooperator and Christian socialist T. Hughes published a seminal scholarly work titled "Foundations: A Study in the Ethics and Economics of the Cooperative Movement" (1879) which contributed to the English cooperators toward the development of the ideology of credit (Webb, 2015).

Fourier's ideas had the strongest influence on the development of the Russian cooperation doctrine. So, the next observation should concern the followers of this movement in the Russian Empire. This list notably includes M. V. Petrashevsky, N. Ya. Danilevsky, I. L. Yastrzhembsky, D. D. Ashkharumov, V. S. Sadovsky, M. I. Tugan-Baranovsky, F. G. Turner and many others who "stepped directly from German philosophy toward Fourier's phalanx...” (Delo Petrashevtsev, 1937: 538).

The ideas of association and Ch. Fourier's views made the subject of some of the articles included in the "Pocket Dictionary" published by M. V. Petrashevsky, specifically "Owenism," "Organic epoch," "Production engineering," "Explanation on the Fourier system," etc. Ch. Fourier's teaching was particularly popular in Russia. Specifically, the N. S. Kashkin circle focused on the legacy of Fourier (Delo Petrashevtsev, 1937). A. I. Herzen believed this particular preoccupation of Russian scholars with Ch. Fourier's ideas could be explained by the resemblance between the phalanx and the traditional Russian commune (which the Petrashevsky circle also found to be the most equitable social form).

Here comes a notable observation of the ideas of A. I. Hertzen concerning the cooperative ideology. E. g., in contrast to many Western socialists' ideas, A. I. Herzen's views of the Russian peasant commune focused on the elements of socialism and included, as one of the main priorities, encouraging entrepreneurial and competitive spirits in peasantry while sticking with the communal principles. The success of the Rochdale Pioneers convinced A. I. Herzen (1955) the former bore the potential of further development of the cooperative movement in England and America, though he pointed at the challenges of competition between such cooperatives with capitalist enterprises.

Democrat and utopian socialist N. G. Chernyshevsky followed A. I. Herzen where it comes to the recognition of the commune as the ideal 
Vladislav Vladimirovich Nevlev, Larisa Vladimirovna Solovyova, Vladislava Igorevna Solovyova, Inna Mikhailovna Nevleva, Anastasia Vladislavovna Nevleva y Vladimir Kuzmich Nevlev

social form. However, being a personality of "tremendous intelligence and tremendous knowledge", according to M. I. Tugan-Baranosky (2010: 2), Chernyshevsky went further in his studies and offered his own accounts on some aspects, particularly, the future socialist economy. The commune fascinated N. G. Chernyshevsky (1950: 619) as a "unity supported and protected by the forces of society itself resulting from the initiative of private individuals". Going further, the development of these forces of communal organisation could make the involvement of central authorities and administration redundant. He defended communal land use as the only possible way to maintain peasants' land possession.

N. G. Chernyshevsky believed that after the land is transferred to private ownership, peasants would inevitably lose possession of it, as private law contained no guarantees to maintain the independence of peasants' enterprise and could not protect it from the danger of being lost to the capitalist system. Even with collective ownership, small private economies would not survive competition against large capitalist enterprises. The only way to conclusively ensure the independence of workers is via "collective production uniting them in partnerships commanding the benefits of largescale production. Thus, the commune is only an initial form."

Chernyshevsky believed that cooperative associations should spread across all areas of the economy and life to become universal. In farming, the association of people in "shared interest communities" should follow the trajectory of advancement of communal principles. In manufacturing, Chernyshevsky (1950: 619) argued, it should also involve a transition of ownership of plants and factories to "collective possessions of all those working at the respective factory or plant" (Chernyshevsky, 1950: 619).

Working on his own "Political Economy for Workers" and a translation of J. S. Mill's "Principles of Political Economy", Chernyshevsky focused on the "fullest development of the communal principle," as well as his own plan of social reorganisation. That plan was largely influenced by the ideas of R. Owen and Ch. Fourier and to some extent Louis Blanc's concept of the system of "social (production farming) workshops" included rules of production engineering and management and also living arrangements for the people. This is a concise outline of the literature for the period.

There are also co-authored papers on the subject in Web of Sciencerated journals focusing on the historical, legal or economic aspects of the development of pre-cooperation in the context of a commune-based society (Nevleva et al., 2020) and on the ethnic and social nature underlying the legal origin of cooperation in the Russian Empire (Nevlev et al., 2021). Also, V. V. Nevlev (2019) takes a legal perspective to consider the roots of cooperation in the West and Russia. 
Some aspects of the problem under study have been reflected or touched on in contemporary articles of journals of the international SKOPUS system.

J. Grashius and M. Elliott (2018) explore the potential role of capital capacity, competition and strategic orientation for mergers and acquisitions of U. S. farmers cooperatives. J. Juga and J. Juntunen (2018) from the University of Oulu analyse the antecedents of retail patronage in the cooperative retail context.

G. McKee, A. Kagan and A. Ghosh (2019) approach executive succession concerns in small asset credit unions. V. Milovanovich, L. Smutka and G. Jusufi (2016) cover the aspects of work cooperation in rice farming in rural Bangladesh.

Developing further the subject of rural cooperation, K. Hakelius (2018) proposes techniques of selecting board composition and interaction patterns in Swedish farm cooperatives. I. Hatak and K. Hyslop (2015) focus on cooperation between family businesses of different sizes

\section{Methods}

The theoretical and methodological basis for writing this work is legislative, regulatory, and instructional documents, certain provisions of legal theory, the history of the state and law, and legal laws. Based on the topic of the problem under study, the methodology of the article was built on a set of methods: universal (dialectics, metaphysics), general scientific (analysis, synthesis, comparison, forecasting, modeling of social and legal processes, systemic and functional) and particular scientific (historical, statistical, formal-legal and comparative-legal).

\section{Results and Discussion}

The theoretical and legal principles of cooperation and, thus, credit cooperation, adopted in Russia were originally laid out by the Western ideologists. And one should draw clear distinctions between the main cooperative doctrines. The socialist concept represented by Robert Owen, Charles Fourier and Philippe Buchez was based on the idea of transformation of a capitalist society into a socialist one. For that, Robert Owen proposed, for example, establishing: "Agricultural and manufacturing villages of unity and mutual cooperation" (Koryakov, 1998: 14).

Formerly a manager of a major enterprise, Owen attempted to transform the moral foundations of the existence of labour and the setbacks he faced drove him to conclude that there was no moral transformation without 
Vladislav Vladimirovich Nevlev, Larisa Vladimirovna Solovyova, Vladislava Igorevna Solovyova, Inna Mikhailovna Nevleva, Anastasia Vladislavovna Nevleva y Vladimir Kuzmich Nevlev

a transformation of the social environment. He thus moved to America and established the community called New Harmony on the land plot he acquired in Indiana. Even though Robert Owen's communist settlements which he called cooperative societies had little resemblance to cooperatives in the modern sense, there is no denial of his role in the development of the foundations of the cooperative ideology.

Charles Fourier believed that rural cooperatives could accumulate the functions of procurement, marketing and credit thus sustaining the full business cycle of an industrial complex. Under Fourier's concept, a community, or a phalange, should be a symbiosis of a commune and a jointstock company forming initial capital from contributions of its members. Income would be distributed in accordance with labour, skills and other inputs - thus, all members of the phalange, including the under-resourced, could eventually become owners of property over time, Fourier believed. The high social ideal sought by Charles Fourier constituted a planned progression of the poor toward the class of small proprietors while bringing the rich more affinity with labour, which would ease class pressures.

Building on Fourier's ideas, the Christian socialist theoretician Philippe Buchez called for the establishment of "production associations" to engage in joint manufacturing operations at the joint expense and further marketing of the output. Such associations, Buchez believed, would replace capitalist enterprise from the market. Thus, socialist ideologists believed the development of cooperation and specifically credit cooperation could help resolve social issues and smooth out political contradictions.

The (charitable and religious) doctrine of support supported most prominently by Wilhelm Raiffeisen (1818-1888) and Victor Huber (18001869) prioritised assistance to the poor in running economic operations. E. g., W. Raiffeisen first founded a rural aid society in Flammersfeld and later a charitable society in Heddesdorf, which were legally half cooperative and half charitable institutions. Yet, the good causes of helping former prisoners, orphaned children and other needy people left Raiffeisen's societies with huge debt.

This led Raiffeisen to establish a credit cooperative of its kind respecting the Commandments of the Gospel. Raiffeisen insisted that the capital of the credit society should remain the undivided property of the society and all excessive gains above a specified threshold should be used for charitable purposes. Notably, the initial capital of such societies primarily flowed in from donations and loans of the wealthy members of the community.

Societies of a similar type as those created by Raiffeisen rejected the idea of equity capital even though the charter of the first Heddesdorf society provided for such capital accruing dividends. Wilhelm Raiffeisen himself strongly opposed the equity system and when all credit cooperatives were 
obliged to have share equity capital after German laws changed, he only settled for nominal compliance with a symbolic amount of equity units. This was quite reasonable given the subject composition of prospective members in credit cooperatives. The under-resourced population in Germany would be challenged by the requirements to contribute any significant amount.

April 25, 1869, is deemed to be the founding date of the first German credit cooperative when the Heddesdorf Benevolent Society set up earlier by Raiffeisen was transformed as a credit society. Its operations ran on nonequity-based principles and consisted in the provision of loans to society members at an interest, while its initial capital was built from external borrowings, not member equity contributions (Antsyferov, 1909).

Loan repayment guarantees were founded on personal trust based on the borrower's moral character. Loans were only available subject to personal acquaintance with the borrower who had to live in the same area with society members. And still, as M. I. Tugan-Baranovsky (2010: 94) reasonably observed, W. Raiffeisen largely viewed credit cooperatives as a tool for a profound "transformation of the contemporary social order to be founded on the basis of Christian duty and brotherly love".

The third ideological movement we would call the dimension of economic efficiency of cooperation was developed by Hermann Schulze-Delitzsch (1808-1883). Without denial of the social aspects of cooperation, he still prioritised the outcomes, i. e., the economic value of such operation. The first credit cooperatives in Germany emerged in response to cash requirements of production societies that lacked funds to purchase materials, which created the need for loans.

Loan-and-savings societies of Schulze-Delitzsch, in contrast to credit cooperatives of Raiffeisen's type, were created to cater to urban populations, specifically petite bourgeoisie, merchants and artisans. Schulze-Delitzsch believed credit cooperation should not be class-based and consolidated the interests of different social strata based on private property and freedom of enterprise.

Interestingly, the organisational and legal status of Schulze-Delitzsch's loan-and-savings societies prompted debate among scholars, specifically, V. A. Kosinsky (1901), M. I. Tugan-Baranovsky (2010) and others. They pointed at the dual nature of loan-and-savings societies showing in two contradictory trends, the need to provide loans to the members on the cheapest possible terms and simultaneously to provide their equity holders with maximum dividends on equity capital. Raiffeisen in his criticism of Schulze-Delitzsch's organisations of cooperative credit reproached the latter for his departure from cooperative objectives in favour of capitalist motives. 
Vladislav Vladimirovich Nevlev, Larisa Vladimirovna Solovyova, Vladislava Igorevna Solovyova, Inna Mikhailovna Nevleva, Anastasia Vladislavovna Nevleva y Vladimir Kuzmich Nevlev

Thus, Schulze-Delitzsch's loan-and-savings societies, among other cooperative organisations, came closest to capitalist enterprise. This is also underscored by the fact that equity capital in Schulze-Delitzsch's loanand-savings societies accrued dividends proportionally to the amount of the society's net income rather than the number of services provided, i. e., loans. Members of societies operating on a model of Schulze-Delitzsch had unlimited joint and several liability within the amount of all their assets, which substantiated the provision of credit.

Cooperation in the modern sense was created artificially. And while capitalist economic management emerged in the natural historical process, cooperation was: "A result of influence on the capitalist society of the socialist ideal" (Tugan-Baranovsky, 2010: 94). Some authors sought to lay theoretical foundations under the ideas of R. Owen, S. Simon and Ch. Fourier, specifically N. G. Chernyshevsky who believed that land communes could provide the basis for establishing production societies; A. I. Herzen who viewed traditional communes as a potential embodiment of communist principles; and M. V. Petrashevsky who understood cooperation as a collective form of consumption and production based on the principles of proportional distribution of goods aligned with labour and capital contributions.

E. g., N. G. Chernyshevsky's works (Chernyshevsky, 1987) substantiated the idea that successful development of agriculture in Russia is only possible if returns are to be ensured on invested capital in the agricultural sector, which, in his view, required market and population growth. Indeed, the small peasant enterprise economy could not compete against major producers, and that created the need for developing a collective form of economic management, communal land management.

N. G. Chernyshevsky believed that traditional communes as a primeval form of land relations could be transformed, by gradual improvements, into an ideal highly developed form of agriculture. The scholar proposed that the state should provide financial support in the form of interest-bearing loans for setting up production and farming societies. The state would also assist in attracting skilled competent talent to lead the association-building process on the new principles.

Society members' earnings, according to Chernyshevsky, should be based on the level of labour input, "The basis for calculation will be a classification of needs taking into consideration what level of labour can go into fulfilling a given need without a loss for other more or less urgent needs" (Nikitina, 1952: 34). The scholar specifically emphasised the principles of freedom universal to all operations of societies, e. g., joining and leaving the ranks, selecting the occupation, lifestyle and residence. 
Similar ideas were consistently proposed by M. V. Petrashevsky, who pinned hopes on the promise of production and consumer associations as a vehicle for a socioeconomic renaissance of the Russian society (Nikitina, 1952). M.V. Petrashevsky understood cooperative forms (M.V.Petrashevsky used the term "associations") potentially as production and consumption arrangements based on the principle of proportional distribution tied to capital, labour and talent inputs.

Many researchers associate the birth of the first credit and consumption cooperativesin Russiaand consumercooperationingeneral with theabolition of serfdom, reforms of local government, education, the development of capitalist relations and other socioeconomic transformations. According to T. A. Seliverstov (2001: 14): "The modern history of cooperation dates back to the mid-19th century and is fully a consequence of the transfer of Western practices to the Russian soil". Let us disagree with this point.

A typical form of social association for mutual assistance and interaction was the traditional peasant commune, which administered economic, fiscal, social and educational functions. Even despite certain resemblance between the institute of cooperation and the peasant commune, more aspects differentiated these phenomena (Nevlev, 2018).

\section{Conclusion}

Early on in the development of the cooperative movement, utopian socialists proposed an idea that cooperation, as a form of economic management, could embody the ideals of a principal new socioeconomic formation. The theoretical basis of cooperation was created by Western ideologists whose views were adapted in the three main collective doctrines in Russia. The first one, the socialist doctrine, developed by C. H. SaintSimon, R. Owen, Ch. Fourier, Ph. Buchez, W. King, P. J. Proudhon, N. G. Chernyshevsky, A. I. Herzen, M. V. Petrashevsky, N. Ya. Danilevsky and others approached cooperation as a tool for the transition to socialism that would provide work and income to the needy and bring the rich more affinity with labour.

The religious and charitable doctrine, or the doctrine of support, supported most prominently by W. Raiffeisen, V. Huber, H. Spencer, A. Comte, P. A. Kropotkin and others, prioritised assistance to the poor in running the cooperative economy. And finally, the third ideological movement, dubbed the dimension of economic efficiency of cooperation was developed by V. S. Sadovsky, F. G. Turner, M. I. Tugan-Baranovsky, V. A. Kosinsky, V. F. Totomiants, L. Blanc, H. Schulze-Delitzsch. The latter approached cooperation in connection with the potential to improve economic performance. 
Vladislav Vladimirovich Nevlev, Larisa Vladimirovna Solovyova, Vladislava Igorevna Solovyova, Inna Mikhailovna Nevleva, Anastasia Vladislavovna Nevleva y Vladimir Kuzmich Nevlev

There were some known forms of primitive cooperation or precooperation over the centuries of Russian history. Those included the peasant commune, artel-based forms of arts and crafts, various institutes of resource-pooling and mutual help, which contributed toward the adoption of credit and consumer cooperation in the living context of the Russian peasantry. Before the revolution, credit cooperation was approached in research as a type of cooperation uniting small rural and urban producers, workers and servicemen to establish a mutual cash fund to meet the requirements in small credit. That said, there were two major forms of credit cooperation during the analysed historical period, namely, mutual loan associations and loan-and-savings societies.

The first Russian association we would refer to, a prototype of a credit cooperative, was the Malaya Artel (small artel) established in 1834 as a mutual aid society resembling the features and functions of a loan-andsavings society. Emerging in the 1830s, consumer credit cooperation only became subject to legal regulation in 1872 when the Model charter of loanand-savings societies was developed and approved.

On June 1, 1895, the Regulation on institutions of small loans was approved, which was the first regulatory act governing the operations of credit organizations and providing for the existence of two types of consumer credit cooperatives, loan-and-savings, and credit societies. The Regulation provided for government aid measures to be supported by the National Bank and available for credit societies; meanwhile it also steppedup control of economic operations run by credit societies, which negated the cooperative principles of autonomy and self-governance.

Credit cooperation was integrated into social practices in Russia in the third quarter of the 19th century amid the advance of exchange relationships, the transition from closed-cycle natural economy arrangements toward the market economy and weakening of the communal form of land management. This institute organically drove artel and commune-based traditions of the rural world, enabling the peasantry to gain the privileges of market-based, financial and industrial urban development while maintaining traditional economic forms. Credit cooperation became a genuine instrument of modernization of the Russian society which contributed to social stability and harmony of the interests of the industrial urban and patriarchal rural environments. 


\section{Bibliographic References ${ }^{7}$}

ANTSYFEROV, Alexey Nikolaevich. 1909. Cooperation in agriculture in Germany and France. Pechatnya S. P. Yakovleva. Voronezh, Russian empire.

BROCKHAUS AND EFRON ENCYCLOPEDIC DICTIONARY. 1895. Vol. 14. Semenovskaya Tipolitografiya (I.A. Yefrona). Saint Petersburg, Russian empire.

BULGAKOV, Sergey Nikolaevich. 1913. History of social teachings in the 19th century. As manuscript. 2nd ed. Publishing commission of the Moscow Commercial Institute. Moscow, Russian empire.

CHERNYSHEVSKY, Nikolay Gavrilovich. 1950. Complete works. Vol. 5. Articles 1858-1859. Goslitizdat. Moscow, USSR.

CHERNYSHEVSKY, Nikolay Gavrilovich. 1987. Kapital i trud [Capital and labour]. Works in two volumes. Vol. 2. Mysl. Moscow, USSR.

COMTE, August. 1912. System of positive polity. Part 1. Rodonachalniki pozitivizma [Founders of positivism]. Tretya tetrad [Third book]. Brokgauz i Yefron. Saint Petersburg, Russian empire.

DELO PETRASHEVTSEV [The case of the Petrashevites]. 1937. Vol. 1. Publishing house of the USSR Academy of Sciences. Moscow, USSR.

GRASHUIS, Jasper; ELLIOTT, M. 2018. "The role of capital capacity, spatial competition and strategic orientation to merges and acquisitions U.S. farmers cooperative" In: Journal of Co - operative Organization and Management. Vol. 6, No. 2, pp. 78-85.

HAKELIUS, Karin. 2018. "Understand the board of Swedish farmer cooperatives - cases focusing on board composition and interactions patterns" In: Journal of Co - operative Organization and Management. Vol. 6, No. 2, pp. 87-96.

HATAK, Isabella; HYSLOP, Katie. 2015. "Cooperation between family business of different sizes: a case study" In: Journal of Co - operative Organization and Management. Vol. 3, No. 2, pp. 52-59.

HERZEN, Alexander Ivanovich. 1955. Collected works issued in 30 volumes. Vol. 5. Publishing house of the USSR Academy of Sciences. Moscow, USSR, pp. 138-168.

7 Some cited sources only have the initial of the name of the author or authors because it was impossible to locate their full name as stable the standard of this journal. 
Vladislav Vladimirovich Nevlev, Larisa Vladimirovna Solovyova, Vladislava Igorevna Solovyova, Inna Mikhailovna Nevleva, Anastasia Vladislavovna Nevleva y Vladimir Kuzmich Nevlev

JUGA, Jari; JUNTUNEN, Jounti. 2018. "Antecedents of retail patronage in cooperative retail context” In: Journal of Co-operative Organization and Management. Vol. 6, No. 2, pp. 10-18.

KORYAKOV, I.A. 1998. Principles of cooperative movement. ZIP SUPK. Chita, Russia.

KOSINSKY, Vladimir A. 1901. Institutions for small loans in Germany. Universitetskaya tipografiya. Saint Petersburg, Russian empire. P. 18.

KROPOTKIN, Petr Alekseevich. 1922. Mutual Aid: a Factor of Evolution. Golos truda. RSFSR. Moscow, URSS.

MARX, Karl; ENGELS, Friedrich. 1961. Selected works. Vol. II. Gospolitizdat. Moscow, USSR.

MCKEE, G.; KAGAN, A.; GHOSH, A. 2019. "Small asset credit union executive succession concerns" In: Journal of Co - operative Organization and Management. Vol. 7, No. 1, pp. 26-33.

MILOVANOVICH, Vladimir; SMUTKA, Luboš; JUSUFI, Gent. 2016. "Cooperative rice farming within rural Bangladesh" In: Asta Universitatis Agriculturae et Silviculturae Mendelianae Brunensia. Vol. 64, pp. 5-12.

NEVLEV, Vladislav Vladimirovich. 2018. Reforms of local self-government in Russia in the 19th century: study guide. OOO Epitsentr. Belgorod, Russia.

NEVLEV, Vladislav Vladimirovich. 2019. Legal retrospective of Western and Russian origins of cooperation: monograph. Epitsentr. Belgorod, Russia. $128 \mathrm{p}$.

NEVLEV, V.V; OLIINYK, O; OLEYNIK, J.A; SOLOVYEVA, L.V; SOLOVYEVA, V.I.; OLEYNIK, N.N. 2021. "Ethno-social nature of legal origin of cooperation in the Russian Empire" In: Revista Tourismo Estudos Praticas. Vol. S1, pp. 1-8.

NEVLEVA, I.M; NEVLEV, V.K; NEVLEV, V. V; SOLOVYEVA, L.V.; SOLOVYEVA, V.I; NEVLEVA, A.V. 2020. "Historical-legal and economic features of pre-cooperation formation in the conditions of community society" In: Revista Inclusiones. Vol. 7, No. 3, pp. 334-345.

NIKITINA, F.G. 1952. "Social and political views of M. V. ButashevichPetrashevsky" In: Iz istorii russkoi filosofii XVIII-XIX vv. [From the history of Russian philosophy of the 18th-19th centuries]: collection of papers. Ed. I. Ya. Schipanov. Moscow University Publishing House. Moscow, USSR, pp. 34-49. 
SADOVSKY, V.S. 1868. On the development of worker associations as a measure of public improvement]. Tip. L. Nitche. Odessa, Russian empire.

SELIVERSTOV, T.A. 2001. Legal regulation of cooperation in Russia in 18651917: abstract dis. ... candidate of legal sciences. Moscow State Law Academy. Moscow, Russia.

SPENCER, H. 1898. The Principles of Sociology. Part 1. Tipografiya Porokhovshchikova. Saint Petersburg, Russian empire, pp. 24-25.

TUGAN-BARANOVSKY, M.I 2010. Social foundations of cooperation. Izdatel'stvo Yurayt. Moscow, Russia.

TUGAN-BARANOVSKY, M.I. 1910. "Social and economic perspectives of N. G. Chernyshevsky" In: Tr. Volnogo ekon. obshchestva [Scientific Works of the Free Economic Society of Russia]. Vol. 1, Book 1. Imp. Akad. Nauk. Moscow, Russian empire.

WEBB, C. 1915. Lives of great men and women: a short biography of some heroes and friends of co-operation]. Authorised translation from English M. Rosenfled. Ed. V.F. Totomiants. Trud. Moscow, Russian empire. 

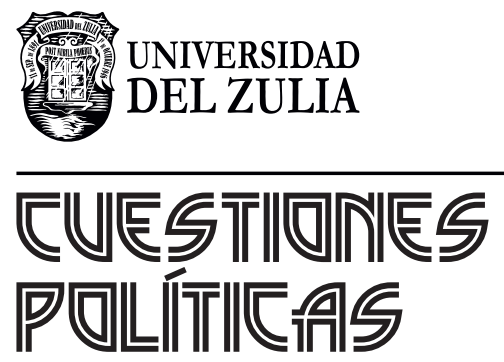

Vol. 39 N $^{\circ} 71$

Esta revista fue editada en formato digital y publicada en diciembre de 2021, por el Fondo Editorial Serbiluz, Universidad del Zulia. Maracaibo-Venezuela 